\title{
Skill-Centered Assessment in an Academic Course: A Formative Approach to Evaluate Student Performance and Make Continuous Quality Improvements in Pedagogy
}

https://doi.org/10.3991/ijet.v14i11.10275

\author{
Khalid Mohiuddin $\left.{ }^{(}\right)$, Mohammad Ashiquee Rasool, \\ Mansoor Shariff, Mohammad Rashid Hussain \\ King Khalid University, Abha, Saudi Arabia \\ drkhalidmk70@gmail.com
}

\begin{abstract}
Practices in domain-referenced assessment design and formative course evaluation are not common in still-developing, higher education systems around the world. This paper demonstrates skill-centered assessment and instructional design as a method for evaluating students' skills performances, and demonstrates how to use the overall results for improving the quality of instruction in a course in computing education. It applies a case study method, describing assessment methods linked to, targeted learning skills and learning domains. The measurements were carried out by the course instructor, adopting a replicable analytic approach. The measured outcomes on each skill provided specific information to guide actions by teachers, to improve course delivery. Results suggest important indicators for teachers to stress in the next cycle of course delivery in which the students were weak. The study demonstrates an easy-toapply approach in skill-centered assessment, starting with assessments linked to learning domains, as a means for promoting best practices in formative evaluation in the field of computer education. While the essential principles of this method date back to the literature on criterion-referenced testing and instructional design, the systematic process produces results to support quality improvements in higher education settings where such methods are not the norm.
\end{abstract}

Keywords - Skill-centered assessment, Learning domains, Formative evaluation, criterion-referenced testing, Higher education, Quality improvement

\section{$1 \quad$ Introduction}

Offering and delivering a high quality education is the responsibility of both teachers and institutions [1]. So as to achieve the desired results by students and the institution as a whole, the department and institution has to support teachers. Since the 1920 s, there have been attempts to search for suitable methods to assess the quality of instruction in higher education institutions. However, there are few examples of skillcentered assessment practices in higher education systems globally, especially in 
computing education programs in the Middle Eastern universities (CITE). Quality assessments of instruction are frequently based on arbitrary or idiosyncratic methods practiced by individual faculty members of higher education institutions. In such assessments, there are no defined principles that guide evaluative actions as, Brooks discuses in Survey of Reissues of U.S. Recordings, 2005. Measuring students' performance in an academic courses in higher education is vital in quality improvement processes [2]. The complexity notably increases when evaluating technical courses which include both theory and laboratory sessions.

In our study, the utility of a skill-centered assessment system is demonstrated for evaluating a core course from the curriculum in computer science education. The course was offered by the department at the College of Computer Science and students' skills in the course were measured [3]. The aim of this study is to demonstrate, using a case study approach, an evaluation of students' performance in the course and the outcomes' measurement [4], using Key Performance Indicators (KPIs).

The skills are tied to learning domains most appropriate for the course. Assessment methods should be developed relative to the targeted KPIs and able to measure students' skills performance of the course learning. The outcomes of the measured performance should be compared with course learning objectives. The comparison result shows students' skills-performance learned from the course contents. The result is analyzed and a summary report is prepared that includes "observations", "recommendations", and "suggested actions" for the performance improvement. The implementation of suggested actions in the next cycle of course-delivery assures quality improvement in students' performance.

The method is consistent with domain-referenced methods of instructional design, also called criterion-referenced test design and use in the educational assessment and evaluation literature; Dick \& Carey discussed in their article, published in 2014, Shepard in, 2006, [5] and [6].

In the demonstrated case, evaluation and measurement were carried out throughout the semester following the course-teaching and assessment plan. During the process, the course skills are assessed following the course specifications (CS). The CS is a precise document that includes all the activities which have to be followed during the course delivery [20]. Each assessment outcome is measured using KPIs, which are defined in form of scoring rubrics shown in Table 6. Based on the KPIs evaluation, the students' performances are analyzed at three levels, satisfactory, developing, and unsatisfactory. Finally, the measured outcomes (numerical data) logically are interpreted into meaningful information and is considered in the next cycle for the performance improvement [8].

The ultimate aim of the skill-based performance measurement is to learn how much skills learned by the students of the course content. The measured outcomes are the improvement indicators for the course as well as for program's improvement planning. This formative evaluation practice is very important [9] to enhance course learning skills [4]. 


\subsection{Contributions and outline}

The study introduces an assessment approach that explains how students' performances in course-skills should be measured applying KPIs rubric. The original contributions of this paper are:

- The skill-centered assessment approach in course skills (Section 4).

- Sample of course assessments policy (Table 1).

- Skills' measuring process applying KPIs rubric (Section 5).

- Course performance analysis (Section 5.2).

- Performances measurements' benchmarking (Section 6).

- The study's approach should be adopted for any data size.

The paper is completed by Section 1, indicates the importance of course-skills measurements in higher education and the purpose of study. Section 2, presents the study's background. Section 3, presents the study environment and the adopted methods. Finally, we present the study's findings and conclude.

\section{Study Background}

In many Gulf countries, quality educational standard were introduced by the National Qualification Framework [20], in the last decade. The idea behind outcome based assessments and performance measurements are practiced in academic institutions across the world. Quality-based educational framework offers common teaching, learning, and assessment methods in higher education [10] . A large number of quality standards have to achieve during a course and an academic program delivery in higher educations [11].

Course assessment and performance measurement are crucial practices for achieving quality standards. Over the decades, numerous assessments and evaluation methods have been recommended for academic programs in higher education [12]. Authors commented on the increasing complexity of academic measurements and the necessity for improving the relevance of assessment data for classroom level stakeholders [13].

In higher educations, more focus has been given to outcome-based course assessments. For determining students' course-learning, outcome based assessment is an important aspect. Many assessment methods have been developed to assess course learnings. Ralph W. Tyler, defines these activities as "evaluation" [14] and the evaluation results are the potential indicators which have to be considered in improving performance quality [15] [16].

At present, many higher education researchers emphasize a learning-centered mode of teaching and outcome-based assessment policies [17] . Because there have been changes to policies with new policies defining standards for higher education [18]. Such policy shifts build pressure on academic institutions to improve curricula, and places a burden on teachers to implement effective assessment practices. 
A recent study [18] described the assessment process based on performance standards and rubrics [19] to measure students' performance. However, teachers should develop learning-centered course plans that should be mapped to outcome-based assessments and address the national standards [20]. The outcome-based or skillsspecific assessments approach should be considered. The approach should be effective in assessing students' performance specifically in a technical course. It is important for quality learning of the course content. Our approach presents skillcentered assessment methods that correspond to outcome-based assessments [21], of an academic course. It also presents students' skills performance measurements using rubrics [19] and applying KPIs evaluation [16].

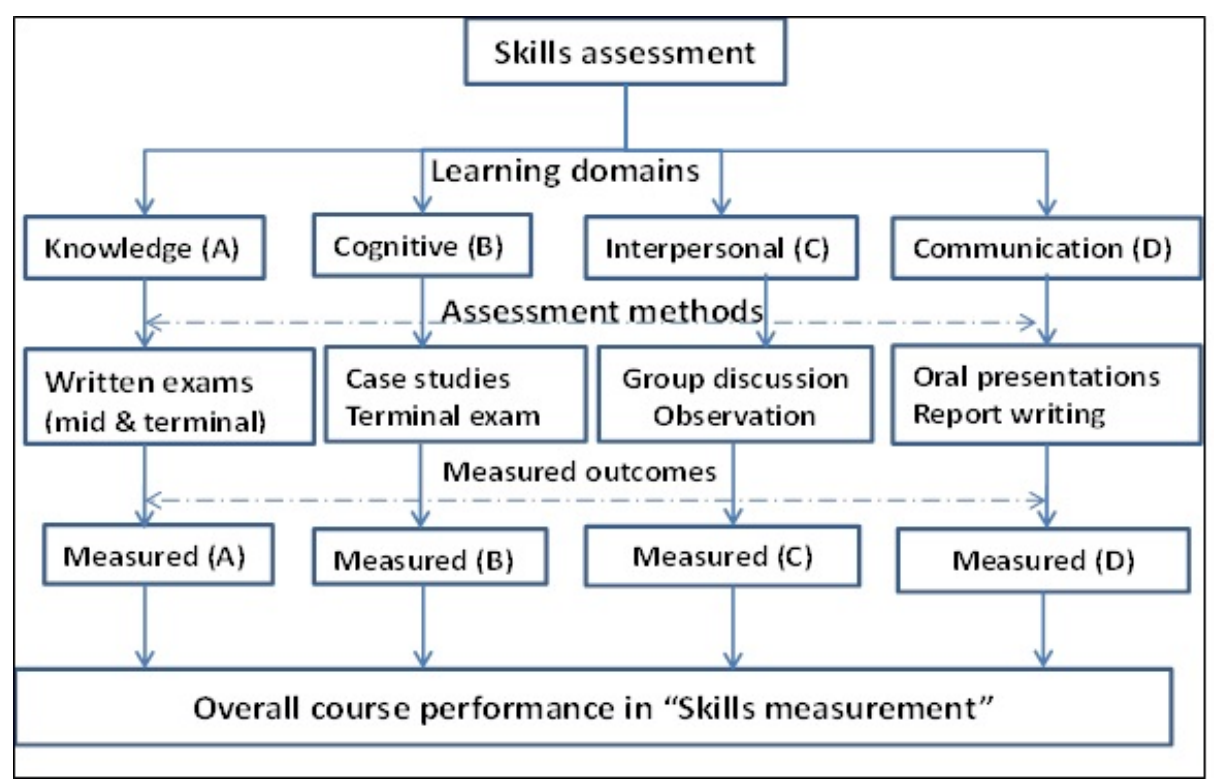

Fig. 1. The skill-centered measurement framework

\section{Methods}

The study evolved at the college of computer science in the university environment. The study's method is based on formative course assessments and students' performance measurement using defined KPIs for the course. It is mixed of descriptive, qualitative and analytic methods. It avoids robust calculations process for the performance measurement such as other mathematical models [19] used for measurements.

The course with the title "Cloud computing concept" was offered to the graduating students at level ten that forms part of the curriculum and degree in computer science at the University. The course was offered for the fall semester, 2017. The authors were among the active participants as course-teachers and lab assistants. The other participants were enrolled students in the course. 
Several assessments (listed in the CS) were conducted during the course delivery. The assessments were designed based on course learning skills. The skill-based students' performances were evaluated and measured by applying KPIs. Usually, the performance measurement is carried out for the enrolled students in the course.

In our case, the offered course is a core course from the curriculum. By the registration rule, the maximum students' enrolment limit for the core courses is twenty. In the current semester, twenty students enrolled for the course, but six students were denied further course completion. Because, they didn't comply the minimum attendance rule. The course has been evaluated on hundred grade points and students' skills performances measured in the four learning domains [20], shown in Table 1. The study should be adopted for any data size.

\subsection{Assessment scheme}

Assessment types, activities, and tasks [19] are defined in the CS [20]. The CS also includes assessments' schedule for the whole contents of the course. The students' skill-based performances were measured after each assessment and the result was recorded for further evaluations at the course completion.

\section{Skill-Centered Approach}

The approach is based on skill-centered, [20] assessment. This helps to improve students' skills performance when delivering the course in the next cycle [21]. We propose the course-skills' measuring aspects and a scientific approach to achieve the intended course learning outcomes.

\subsection{Policy}

At the beginning of the course delivery, both the course teacher and the course coordinator decide the course evaluation and measurement policy. The course assessment policy for the current semester is prepared based on the previous course assessment report; it has to be followed in the course assessments in the current semester. The students' performances are measured and compared with the intended course learning outcomes [11]. Generally, the course can be assessed by two approaches, first, measure the course learning outcomes (CLOs) using assessment methods and rubrics (listed in CS). The second one is skill-centered assessment approach that evaluates students' skills performance learned of the course content [20]. We followed the latter approach.

Table 1 describes the skill-centered assessments' policy for the current semester. The second column shows the course learning skills and corresponding learning domains. Column five describes chosen assessment methods for measuring students' skills performance. 
Table 1. Skill-centered assessment policy for the current semester

\begin{tabular}{|c|l|c|l|l|c|}
\hline S.N & $\begin{array}{l}\text { Learning skills } \\
\text { \& domains }\end{array}$ & $\begin{array}{c}\text { Domain } \\
\text { code }\end{array}$ & \multicolumn{1}{|c|}{ Possible assessment methods } & Chosen methods & $\begin{array}{c}\text { Grades } \\
\text { share in (\%) }\end{array}$ \\
\hline 1 & Knowledge & A & $\begin{array}{l}\text { Written exams, short \& long essays, } \\
\text { quizzes }\end{array}$ & Written exams & 40 \\
\hline 2 & Cognitive & B & $\begin{array}{l}\text { Case studies, long essays, mini } \\
\text { project }\end{array}$ & $\begin{array}{l}\text { Case studies } \\
\text { Long essays }\end{array}$ & 25 \\
\hline 3 & Interpersonal & C & $\begin{array}{l}\text { Group discussion, a real time case, } \\
\text { observation (visit to IT center) }\end{array}$ & $\begin{array}{l}\text { Group discussion } \\
\text { Observation }\end{array}$ & 20 \\
\hline 4 & Communication & D & $\begin{array}{l}\text { Oral presentations, mock interview, } \\
\text { report writing }\end{array}$ & $\begin{array}{l}\text { Oral presentation } \\
\text { Reports writing }\end{array}$ & 15 \\
\hline
\end{tabular}

\subsection{Measuring methods}

Herein the assessment methods [26] and assessment activities have been discussed for the students' performance measurement in the course-skills.

Knowledge: We choose knowledge domain first, because it is the basic building block of the course. For this case, we decided to measure students' performance through written exams. The written exams were in two formats, midterm and terminal exams. Questions were framed and grouped into different sections with respect to the basic course knowledge shown in Table 2. The measuring process and the outcomes discusses in section 5 .

Table 2. Assessment methods in knowledge domain

\begin{tabular}{|l|l|l|c|c|}
\hline $\begin{array}{c}\text { Domain type } \\
\text { with code }\end{array}$ & $\begin{array}{c}\text { Assessment method- } \\
\text { type }\end{array}$ & Assessment activity & $\begin{array}{c}\text { Grades share } \\
\text { in (\%) }\end{array}$ & $\begin{array}{c}\text { Instruction for the } \\
\text { students }\end{array}$ \\
\hline Knowledge (A) & $\begin{array}{l}\text { Midterm exam } \\
\text { (written) }\end{array}$ & $\begin{array}{l}\text { Fill-in-the blanks } \\
\text { True / falls } \\
\text { Multiple choice ques- } \\
\text { tions } \\
\text { Short essays }\end{array}$ & 20 & $\begin{array}{l}\text { All questions are } \\
\text { compulsory; it is } \\
\text { necessary to write in } \\
\text { the provided answer } \\
\text { sheet only }\end{array}$ \\
\cline { 2 - 4 } & $\begin{array}{l}\text { Terminal exam } \\
\text { (written) }\end{array}$ & $\begin{array}{l}\text { Question types of mid } \\
\text { exam \& long essays }\end{array}$ & 20 & \\
\hline
\end{tabular}

Table 2 describes the domain type, assessment methods and assessment activities, and grade share. The sample of assessment data collected is shown in table 7 .

Cognitive: Cognitive skills are the advancement of knowledge-based. This skill should be measured [19] [23], in two formats, as shown in table 3. First, using the case studies and the second one is terminal exam. 
Table 3. Assessment methods for cognitive skills

\begin{tabular}{|l|l|l|c|l|}
\hline $\begin{array}{l}\text { Domain type } \\
\text { with code }\end{array}$ & $\begin{array}{c}\text { Assessment } \\
\text { method-type }\end{array}$ & \multicolumn{1}{|c|}{ Assessment activity } & $\begin{array}{c}\text { Grades share } \\
\text { in (\%) }\end{array}$ & \multicolumn{1}{|c|}{$\begin{array}{c}\text { Instruction for the } \\
\text { students }\end{array}$} \\
\hline \multirow{2}{*}{$\begin{array}{l}\text { Cognitive } \\
\text { (B) }\end{array}$} & Case studies & $\begin{array}{l}\text { Case-scenarios: problems- } \\
\text { solution in the adoption of cloud } \\
\text { technology by organizations }\end{array}$ & 15 & $\begin{array}{l}\text { Real-time cases, from } \\
\text { the prescribed text book } \\
\& \text { other resources }\end{array}$ \\
\cline { 2 - 5 } & $\begin{array}{l}\text { Terminal } \\
\text { exam }\end{array}$ & $\begin{array}{l}\text { long essays- } \\
\text { (cognitive questions) }\end{array}$ & 10 & $\begin{array}{l}\text { Three questions on the } \\
\text { skills }\end{array}$ \\
\hline \multicolumn{2}{|r|}{ Total grade share from Table 1 } & 25 & \\
\hline
\end{tabular}

Interpersonal: The assessment methods for this skill are 'group-discussion' and 'observation'. Group-discussions were held, interaction between two or more students was practiced. One student as IT manager (ITM) and the other one as finance manager (FM).

- Case 1(group discussion): ITM asks funds to upgrade existing technology and explains the needs, for the adoption of cloud computing technology.

- Case 2 (group discussion): FM (after 6 weeks) seeks the report about the funds utilization and the performance of adopted technology.

For the observation method, both course coordinator and course teachers plan students' visit to IT-center. They observed the skills and professional ethics performed by the students during the visit. Evaluate students' performances and records the measured outcomes for further course compilation.

Communication: The assessment methods for the communication skills were analytical, 'report-writing' and 'presentations' on the given topic and the visit to 'ITcenter'. The students have to attempt both to obtain the grade for the skills.

Table 4. Assessment methods for interpersonal skills

\begin{tabular}{|l|l|l|c|c|}
\hline $\begin{array}{c}\text { Domain type } \\
\text { with code }\end{array}$ & $\begin{array}{l}\text { Assessment method- } \\
\text { type }\end{array}$ & Activities on assessment & $\begin{array}{c}\text { Grades } \\
\text { share in (\%) }\end{array}$ & $\begin{array}{c}\text { Instruction for the } \\
\text { students }\end{array}$ \\
\hline $\begin{array}{l}\text { Interpersonal } \\
\text { (C) }\end{array}$ & $\begin{array}{l}\text { Group discussion- } \\
\text { interaction between } \\
\text { two or more students } \\
\text { as ITM \& FM }\end{array}$ & $\begin{array}{l}\text { Case1: ITM vs. FM series of } \\
\text { interaction } \\
\text { Case2- FM vs. ITM- feed- } \\
\text { back on performance }\end{array}$ & 10 & $\begin{array}{l}\text { Case1 \& 2: scenarios- } \\
\text { based discussion }\end{array}$ \\
\cline { 2 - 5 } & $\begin{array}{l}\text { Observation } \\
\text { of IT- center visit }\end{array}$ & $\begin{array}{l}\text { Interact the officials and } \\
\text { professionals }\end{array}$ & 10 & $\begin{array}{l}\text { Demonstrate the skills, } \\
\text { get the required Info. }\end{array}$ \\
\hline
\end{tabular}

Table 5. Assessment methods for communication skills

\begin{tabular}{|l|l|l|c|l|}
\hline $\begin{array}{c}\text { Domain type } \\
\text { with code }\end{array}$ & \multicolumn{1}{|c|}{$\begin{array}{c}\text { Assessment } \\
\text { method-type }\end{array}$} & Activities on assessment & $\begin{array}{c}\text { Grades } \\
\text { share in (\%) }\end{array}$ & \multicolumn{1}{|c|}{$\begin{array}{c}\text { Instruction for the } \\
\text { students }\end{array}$} \\
\hline \multirow{2}{*}{$\begin{array}{l}\text { Communication } \\
\text { (D) }\end{array}$} & Oral presentation & $\begin{array}{l}\text { Presentations on the given } \\
\text { topic and on the visit to IT } \\
\text { center }\end{array}$ & 05 & $\begin{array}{l}\text { Demonstrate presentation } \\
\text { dynamic }\end{array}$ \\
\cline { 2 - 5 } & Report writing & $\begin{array}{l}\text { Analytical reports on the } \\
\text { visit to IT-center }\end{array}$ & 10 & $\begin{array}{l}\text { A comprehensive re- } \\
\text { port(s) }\end{array}$ \\
\hline \multicolumn{2}{|l}{ Total grade share from Table 1 } & 15 & \\
\hline
\end{tabular}




\subsection{Limitations and challenges}

Following are the limitations and challenges when measuring students' skills performance in a technical course:

- Specific documents are required exclusively developed for the course.

- Both theory and lab segments have to be assessed and measured.

- Define appropriate KPIs to measure the course-skills, shown in Rubric table 6.

- Record each assessment's outcomes for measuring overall course performance and for the next course delivery for the performance improvement.

- Required the previous semester's course assessments data for the benchmarking and setting up the new targets, shown in benchmarking table 12 .

- Time consuming; have to integrate the skill's performance measured data to analyze the overall course performance.

- Interpret the measured numerical data into summary reports.

- The effective implementation of the suggested actions from the previous semester's course assessments report. It has to be applied in the current semester to determine the performance improvement.

\section{$5 \quad$ Measuring Process}

The course skills' measurements were done using KPIs [24]. Each skill's performance is measured using KPIs' in rubric [25] form. The whole approach is based on minimum scientific calculation.

Table 6 describes the sample of KPIs (a1 and a2) of (a1-a5) defined for the course skills. Students' performances measured applying KPIs evaluation description and obtained the result into three performance levels $(l 1, l 2$, and $l 3)$.

Table 7 represents the sample of single student's performance in the assessment for knowledge domain, described in table 2. Similarly, the data has been collected for all the students who have participated in the assessment. The performance has been graded into three levels as 'S-satisfactory', 'D-developing', and 'U-unsatisfactory'. It also shows the students' obtained with $(\checkmark)$. Similarly, the assessment result is collected for the rest of the students, shown in table 8 .

Table 6. Rubric, sample of KPI's evaluation for the knowledge domain

\begin{tabular}{|c|c|c|c|}
\hline \multicolumn{4}{|c|}{ KPI evaluation description } \\
\hline KPIs & Satisfactory- $l_{1}$ & Developing- $l_{2}$ & Un-satisfactory- $l_{3}$ \\
\hline $\begin{array}{l}\text { KPI-1 (a1): Recognize } \\
\text { contemporary issues in } \\
\text { the adoption of cloud } \\
\text { technology }\end{array}$ & $\begin{array}{l}\text { Able to recognize most of } \\
\text { the contemporary issues in } \\
\text { adopting cloud services }\end{array}$ & $\begin{array}{l}\text { Able to recognize some of } \\
\text { the contemporary issues in } \\
\text { adopting cloud services }\end{array}$ & $\begin{array}{l}\text { Unable to recognize the } \\
\text { major contemporary } \\
\text { issues in adopting cloud } \\
\text { services }\end{array}$ \\
\hline $\begin{array}{l}\text { KPI-2 (a2): Determine } \\
\text { appropriate resources } \\
\text { needed to solve problems }\end{array}$ & $\begin{array}{l}\text { Capable of determining } \\
\text { appropriate resources } \\
\text { needed to solve problems }\end{array}$ & $\begin{array}{l}\text { Capable of determining } \\
\text { some of the resources } \\
\text { needed to solve problems }\end{array}$ & $\begin{array}{l}\text { Not capable of determin- } \\
\text { ing resources needed to } \\
\text { solve problems }\end{array}$ \\
\hline
\end{tabular}


Table 7. Student's performance sample obtained in knowledge domain

\begin{tabular}{|c|c|c|c|c|c|c|}
\hline $\begin{array}{l}\text { University ID: } 433822625 \\
\text { puting }\end{array}$ & & & & ys & & \\
\hline Semester: I, Fall, 2017 & & & & & & \\
\hline Assessn & mes & & & Dom: & owl & \\
\hline KPI-code(a1-a5) & & 1( & & & & \\
\hline levels (L) & $\mathrm{S}$ & $\mathrm{D}$ & $\mathrm{U}$ & $\mathrm{S}$ & $\mathrm{D}$ & $\mathrm{U}$ \\
\hline Obtained & $\checkmark$ & & & & $\checkmark$ & \\
\hline
\end{tabular}

Table 8. The assessment result of fourteen students in knowledge domain

\begin{tabular}{|c|c|c|c|c|c|}
\hline $\begin{array}{c}\text { Domain } \\
\text { types }\end{array}$ & $\begin{array}{c}\text { Level 1: }\left(\mathbf{l}_{\mathbf{1}}=\mathbf{3}\right) \\
\text { (Satisfactory) }\end{array}$ & $\begin{array}{c}\text { Level 2: } \mathbf{l}_{\mathbf{2}}=\mathbf{2} \text { ) } \\
\text { (Developing) }\end{array}$ & $\begin{array}{c}\text { Level 3: }\left(\mathbf{l}_{\mathbf{3}}=\mathbf{1}\right) \\
\text { (Unsatisfactory) }\end{array}$ & $\begin{array}{c}\text { Total } \\
\text { Number (N) }\end{array}$ & $\begin{array}{c}\text { PS-scale, Per- } \\
\text { formance out of } \\
\mathbf{5}\end{array}$ \\
\hline Knowledge & $\mathrm{n}_{1}=04$ & $\mathrm{n}_{2}=06$ & $\mathrm{n}_{3}=04$ & 14 & 3.33 \\
\hline
\end{tabular}

Table 8 describes the assessment result of the fourteen students and their obtained into performance levels. The result is obtained for all the fourteen students by applying KPIs' rubrics using Table 6 . The values against variables $\mathrm{n}_{1}, \mathrm{n}_{2}, \mathrm{n}_{3}$ are the number of students at each level of performance $l_{1}, l_{2}, l_{3}$ respectively [22].

The following scientific process adopted to measure the fourteen students' performance which appeared in the assessment.

$$
K D=\frac{\left(n_{1} * l_{1}\right)+\left(n_{2} * l_{2}\right)+\left(n_{3} * l_{3}\right)}{(\mathrm{L} * \mathrm{~N})} * \mathrm{PS}
$$

In equation (1), 'KD' is the knowledge-domain code. The variables $\mathrm{n}_{1}, \mathrm{n}_{2}, \mathrm{n}_{3}$ are three groups of students' performances and $l_{1}, l_{2}, l_{3}$, are the three levels of performance. 'PS' is, the performance scale i.e. 5. ' $\mathrm{L}$ ' is the total number of performance levels and ' $\mathrm{N}$ ' is the total number of students, from Table 8.

$$
\begin{aligned}
& K D=\frac{(4 * 3)+(6 * 2)+(4 * 1)}{(3 * 14)} * 5 \\
& K D=\frac{(28)}{(42)} * 5 \\
& K D=3.33, \text { is the students' measured performance in the knowledge domain. }
\end{aligned}
$$

Similarly, the whole process is repeated for the other three domains and the course learning skills are measured by applying equation (1), shown in learning skills Table 9.

Table 9 represents the students' performances measured in the three skills: cognitive, interpersonal, and communication. For measuring the students' performances in each skill, equation (1) and tables 6,7 , and 8 are used. The measurement processes for the three skills are as similar as of the knowledge domain. Variable ' $N$ ' describes the total number of students which have participated in all the assessments. The last column shows the measured performance on the scale of 5 . 
Table 9. The students' performances in course learning skills

\begin{tabular}{|l|c|c|c|c|c|}
\hline $\begin{array}{c}\text { Domain types or } \\
\text { skills-types }\end{array}$ & $\begin{array}{c}\left.\text { Level 1: } \mathbf{(}_{\mathbf{1}}\right) \\
\text { (Satisfactory) }\end{array}$ & $\begin{array}{c}\text { Level 2: }\left(\mathbf{l}_{\mathbf{2}}\right) \\
\text { (Developing) }\end{array}$ & $\begin{array}{c}\text { Level 3: }\left(\mathbf{l}_{\mathbf{3}}\right) \\
\text { (Unsatisfactory) }\end{array}$ & $\begin{array}{c}\text { Total students } \\
\mathbf{N}\end{array}$ & $\begin{array}{c}\text { Performances on } \\
\text { scale 5 }\end{array}$ \\
\hline Cognitive & 03 & 05 & 06 & 14 & 2.98 \\
\hline Interpersonal & 04 & 04 & 06 & 14 & 3.09 \\
\hline Communication & 03 & 03 & 08 & 14 & 2.74 \\
\hline
\end{tabular}

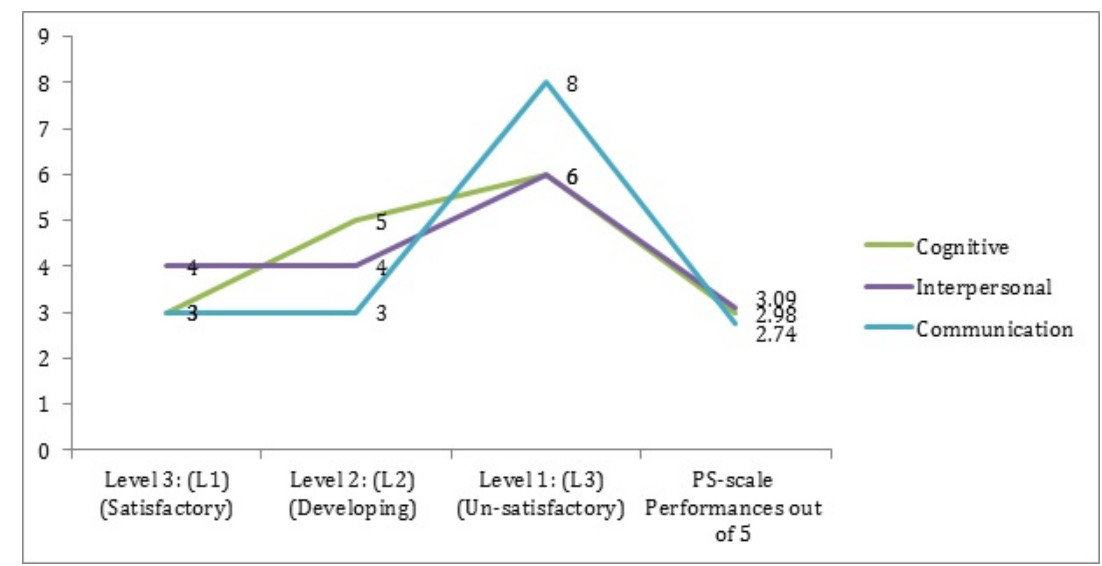

Fig. 2. The skills' performances are measured on scale five

\subsection{Measured skills analysis}

The students' skills performances are analyzed on the performance scale 5, from Table 9. The outcomes are the important indicators to understand the students' skills performances learned of the course skill.

- Cognitive skill: 'unsatisfactory', $-(2.98>2.5$ and $<3)$,

- Interpersonal skill: 'developing' - $(3.09>3)$.

- Communication skill: 'unsatisfactory', - (2.74 > 2.5 and < 3).

The overall course learning and the final performance measurement is obtained by adding all the measured performances. It is obtained by applying equations 2 and 3 .

$$
\mathrm{CP}=\mathrm{DS} / 4 \text {, }
$$

Where ' $\mathrm{CP}^{\prime}$ is course performance and 'DS' is sum of the domains

$\mathrm{DS}=\mathrm{A}($ knowledge $)+\mathrm{B}($ cognitive $)+\mathrm{C}($ interpersonal $)+$ $\mathrm{D}$ (communication)

DS $=3.33+2.98+3.09+2.74=12.14$, values from both tables $8 \& 9$

DS $=12.14$, It is sum of the course learnings

$\mathrm{CP}=3.035$, is the overall skill' performance measured by applying equation (2) 


\subsection{Course analysis}

By following the course specification, students' performances have to be integrated at grade points hundred for measuring the course performance.

First, we measure the course performance at satisfactory level. It is obtained by adding 'satisfactory' performances from all the domains. Variables $\left(\mathrm{A}_{\text {sat }}, \mathrm{B}_{\text {sat }}, \mathrm{C}_{\mathrm{sat}}, \mathrm{D}_{\text {sat }}\right)$, describe learning domains (A-D) and 'sat' describes the grade 'satisfactory' of the course. ' $\mathrm{SL}_{\mathrm{avg}}$ ', represents satisfactory-level (SL) and 'avg' as average.

$$
\mathrm{SL}_{\mathrm{avg}}=\left(\left(\mathrm{A}_{\mathrm{sat}}+\mathrm{B}_{\mathrm{sat}}+\mathrm{C}_{\mathrm{sat}}+\mathrm{D}_{\mathrm{sat}}\right) / \mathrm{N}\right) / 4
$$

$$
\left.\mathrm{SL}_{\mathrm{avg}}=(4+3+4+3) / 14\right) / 4
$$

The variables' values of 'satisfactory' level, taken from the Tables 8 and 9 and applying equation (4)

$\mathrm{SL}_{\text {avg }}=0.25 * 100$ (grade points)

$\mathrm{SL}_{\mathrm{avg}}=25 \%$, is the average of grade 'satisfactory' of the overall course measured.

Similarly, applying equation (4), to achieve the average of grades, 'developing' and 'unsatisfactory' are taken from the tables 8 and 9 .

$\mathrm{DL}_{\mathrm{avg}}=42.85 \%$ is obtained for 'developing'

$\mathrm{USL}_{\mathrm{avg}}=32.15 \%$ is obtained for 'unsatisfactory'

Table 10. The grade shared at each performance level

\begin{tabular}{|c|c|c|c|}
\hline \multicolumn{5}{|c|}{ Course measured performance } \\
\hline Performance levels (grades) & Satisfactory & Developing & Un-satisfactory \\
\hline Measured percentage of each grade & $25 \%$ & $42.85 \%$ & $32.15 \%$ \\
\hline
\end{tabular}

\subsection{Interpreting result data}

It has to interpret the measured course performance (numerical data) of Table 10 into meaningful information shown in Table 11.

Table 11.

The course performance report

\begin{tabular}{l} 
Observation: \\
\begin{tabular}{l} 
Only few students could express the course skills reasonably well. \\
Some students showed their learned skills with appropriate understanding. \\
A number of students couldn't perform the basic understanding of course-skills. \\
\hline \multicolumn{1}{c|}{ Recommendations: } \\
Majority of the students must improve their learning ability. \\
Students should be careful in attempting the assessments, appropriately. \\
Some of the students should realize their minor mistakes which had affected their performance. \\
\hline \multicolumn{1}{c|}{ Suggested actions: } \\
Conduct some sessions of motivation and brainstorming; students must attain communication skills lecture \\
or teacher must provide guidance on regular basis. \\
Teachers have to guide students the appropriate way of doing assessments. \\
Teachers have to convey, students' shortcomings to enhance their performance.
\end{tabular} \\
\hline
\end{tabular}




\section{Benchmarking}

The students' measured skills performances have to be benchmarked with previous performances and set new benchmarks for the next cycle of course delivery and performance evaluation. These indicators should be focused while delivering the course in the next cycle.

Table 12 shows the skills' performance measurements in the fall semester, 2017. New targets and external benchmark set by the stakeholders [20], for the spring semester, 2018. The external benchmark is set by the established external advisory board.

Table 12. The measured outcomes and benchmarking

\begin{tabular}{|c|c|c|c|}
\hline \multicolumn{2}{|c|}{ Fall semester, 2017} & \multicolumn{2}{c|}{ Spring semester, 2018 } \\
\hline Course learning & Measured & New target & External benchmark \\
\hline Knowledge & 3.33 & 3.75 & 4.0 and above \\
\hline Cognitive & 2.98 & 3.15 & 3.50 \\
\hline Interpersonal & 3.09 & 3.20 & 3.50 \\
\hline Communication & 2.74 & 3.00 & 3.50 and above \\
\hline
\end{tabular}

\subsection{Findings}

- Students' performances are reasonably good in expressing the course knowledge.

- Students are weak in displaying the cognitive learning of the course.

- Students have gained a little command of the course skills.

- Some students' performances are very weak in expressing course learning skills.

\section{Conclusion and Discussion}

In line with other researches [25] [28][29] [30], the result of our study provides a comprehensive approach to evaluate students' skills performances; gained of the course contents. It fills the literature lacuna for measuring course-skills by applying KPIs rubric. The skill-specific assessment methods adequately have adopted to determine the students' performances in course learnings [30]. For the performance measurement, the scientific approach, sample size, and participants are common in all the assessments. The performances measured in the course skills are $(A=3.33, B=$ $2.98, C=3.09$, and $D=2.74$ ) and 3.035 is the overall course performance. The course performance on grade-points hundred is rated into three levels of standards, 'satisfactory $=25 \%$ ', 'developing $=42.85$ ', \& 'un-satisfactory $=32.15$ '. The course measured data is interpreted into report that includes observations, suggestions, and recommended actions.

Further, the students' skills performances have to be benchmarked to determine the performance improvement. The outcomes of both course and skills performance 
measurements are the potential indicators, which helps in improving the quality of learning and teaching [28] in the next cycle of course delivery.

Finally, the study findings describe as: the performance is reasonably good in expressing the course knowledge. The students' performances are weak in, displaying cognitive learning of the course. Students have a little command in displaying interpersonal skills and needs improvement. Whereas, the performance in communication skills is unsatisfactory, focused mechanism is required to improve the skills.

The conclusion is that, it is an efficient way of measuring students' performances in leaned skills of the course contents. The approach should be adopted for measuring skills' performances in any technical course in higher education.

Based on the result analysis, we got the skills-performances and the important indicators. These indicators definitely will support stakeholders to prioritize the learning approach to improve performance and achieved desired results. Truly, the adoption of this approach and the effective implementation on the suggested actions, assures quality improvement in the next cycle of performance evaluation.

\section{Acknowledgement}

The authors would like to express their gratitude to King Khalid University, Saudi Arabia for providing administrative and technical support.

\section{References}

[1] S. Van Schalkwyk, B. Leibowitz, N. Herman, and J. Farmer, "Reflections on professional learning: Choices, context and culture," Stud. Educ. Eval., vol. 46, pp. 4-10, 2015. https://doi.org/10.1016/j.stueduc.2015.03.002

[2] "A TEST OF LEADERSHIP Pre-Publication Copy September 2006," 2006

[3] M. I. Núñez-Peña, R. Bono, and M. Suárez-Pellicioni, "Feedback on students' performance: A possible way of reducing the negative effect of math anxiety in higher education," Int. J. Educ. Res., vol. 70, pp. 80-87, 2015. https://doi.org/10.1016/j.ijer.2015. 02.005

[4] S. Kim Sokoya, "Measuring Quality in Graduate Education: A Balanced Scorecard Approach."

[5] R. W. (Ralph W. Tyler and P. S. Hlebowitsh, Basic principles of curriculum and instruction. .

[6] L. Lohr, "Book Reviews," 2006.

[7] S. A. ncaaa, "Reference Documents/Specialized Standards \&amp; Learning Outcomes." [Online]. Available: http://www.ncaaa.org.sa/en/Releases/Pages/ReferenceDocs.aspx. [Accessed: 16-Feb-2017].

[8] D. H. Caro, J. Lenkeit, and L. Kyriakides, "Teaching strategies and differential effectiveness across learning contexts: Evidence from PISA 2012," Stud. Educ. Eval., vol. 49, pp. 30-41, 2016. https://doi.org/10.1016/j.stueduc.2016.03.005

[9] M. Scriven, "Types of Evaluation and Types of Evaluator," Am. J. Eval., vol. 17, no. 2, pp. 151-161, Jun. 1996.

[10] R. Smit and T. Birri, "Assuring the quality of standards-oriented classroom assessment with rubrics for complex competencies," 2014. https://doi.org/10.1016/j.stueduc.2014.02. $\underline{002}$

[11] "Quality Assurance for Higher Education What We Believe Quality Assurance Framework," 2015. 
[12] S. Van Schalkwyk, B. Leibowitz, N. Herman, and J. Farmer, "Reflections on professional learning: Choices, context and culture," Stud. Educ. Eval., vol. 46, pp. 4-10, 2015. https://doi.org/10.1016/j.stueduc.2015.03.002

[13] "The Challenges of Transformation in Higher Education and Training Institutions in South Africa Saleem Badat," 2010.

[14] Ralph W. Tyler, "Ralph W. Tyler (1902-1994) - Contribution to Testing and Curriculum Development, Advisory Role - School, Educational, Education, and University StateUniversity.com," StateUniversity.com. [Online]. Available: http://education. stateuniversity.com/pages/2517/Tyler-Ralph-W-1902-1994.html. [Accessed: 15-Nov2017]. https://doi.org/10.4135/9781412957403.n439

[15] J. P. Robert Glaser, Anthony Nitko, "Criterion-referenced Measurement: An Introduction W. James Popham - Google Books," amazon.com. [Online]. Available: https://books.google.com.sa/books?id=29zOPEuqfzIC\&pg=PR15\&lpg=PR15\&dq=Robert +Glaser,+Anthony+Nitko,+James+Popham\&source=bl\&ots=UIBWNFmfg-

\&sig=Tv8Xb29r6ceni iJGSD5w4svST4\&hl=en\&sa=X\&ved=0ahUKEwjBsM7UrprXAh XC1xoKHR2EDoMQ6AEIKTAB\#v=onepage\&q=Robert\%2520Glaser\%25. [Accessed: 15-Nov-2017].

[16] P. J. Ballard, "ScholarWorks at WMU Measuring Performance Excellence: Key Performance Indicators for Institutions Accepted into the Academic Quality Improvement Program (AQIP)."

[17] S. Badat, "Studies in Higher Education Theorising institutional change: post-1994 South African higher education," vol. 34, no. 4, pp. 455-467, 2009. https://doi.org/10.1080/0 $\underline{3075070902772026}$

[18] M. Aoudia, K. Marji, and D. A.-D. AlQahsi, "Assessment of Higher Education Quality by Using Cohort of First-year in University," Procedia - Soc. Behav. Sci., vol. 191, pp. 330335, 2015. https://doi.org/10.1016/j.sbspro.2015.04.310

[19] S. P. Klein, G. Kuh, M. Chun, L. Hamilton, and R. Shavelson, "An Approach to Measuring Cognitive Outcomes Across Higher Education Institutions," Res. High. Educ., vol. 46, no. 3, pp. 251-276, May 2005. https://doi.org/10.1007/s11162-004-1640-3

[20] M. Baeten, K. Struyven, and F. Dochy, "Student-centred teaching methods: Can they optimise students' approaches to learning in professional higher education?," Stud. Educ. Eval., vol. 39, no. 1, pp. 14-22, 2013. https://doi.org/10.1016/j.stueduc.2012.11.001

[21] M. H. Yarmohammadian, M. Mozaffary, and S. S. Esfahani, "Evaluation of quality of education in higher education based on Academic Quality Improvement Program (AQIP) Model," Procedia - Soc. Behav. Sci., vol. 15, pp. 2917-2922, 2011. https://doi.org/10.1 016/j.sbspro.2011.04.214

[22] Organisation for Economic Co-operation and Development., Measuring improvements in learning outcomes : best practices to assess the value-added of schools. OECD, 2008. https://doi.org/10.1787/9789264050259-en

[23] T. Voss, "Teachers' General Pedagogical/Psychological Knowledge: Conceptualization and Test Construction."

[24] F. Azma, "The quality indicators of information technology in higher education," in Procedia - Social and Behavioral Sciences, 2011, vol. 30, pp. 2535-2537. https://doi.org/ 10.1016/j.sbspro.2011.10.494

[25] [25] R. Smit and T. Birri, "Assuring the quality of standards-oriented classroom assessment with rubrics for complex competencies," Stud. Educ. Eval., vol. 43, pp. 5-13, 2014. https://doi.org/10.1016/j.stueduc.2014.02.002

[26] P. J. Ballard, "ScholarWorks at WMU Measuring Performance Excellence: Key Performance Indicators for Institutions Accepted into the Academic Quality Improvement Program (AQIP)."

[27] "Kingdom of Saudi Arabia National Commission for Academic Accreditation \&amp; Assessment NCAAA Key Performance Indicators."

[28] N. Mora, S. Caballe, and T. Daradoumis, "International journal of emerging technologies in learning.," Int. J. Emerg. Technol. Learn., vol. 11, no. 07, pp. 41-51, Jul. 2016. https:// doi.org/10.3991/ijet.v11i07.5882 
[29] G. M. N. Isabwe, F. Reichert, M. Carlsen, and T. A. Lian, "International journal of emerging technologies in learning.," Int. J. Emerg. Technol. Learn., vol. 9, no. 2, pp. 2936, Mar. 2014. https://doi.org/10.3991/ijet.v9i2.3219

[30] A. Marks, M. AL-Ali, M. Majdalawieh, and A. Bani-Hani, "International journal of emerging technologies in learning.," Int. J. Emerg. Technol. Learn., vol. 12, no. 11, pp. 4 14, Nov. 2017. https://doi.org/10.3991/ijet.v12i11.6987

[31] K. Matchett, M. L. Dahlberg, and T. Rudin, Eds., Quality in the Undergraduate Experience. Washington, D.C.: National Academies Press, 2016.

\section{Authors}

Dr. Khalid Mohiuddin holds a PhD in Computer Science and is recognized as researcher, and an excellent teaching practitioner at the faculty of Computer Science at King Khalid University, Saudi Arabia. His interdisciplinary research involves cloud computing, mobile cloud, cloud intelligence, academic research, educational evaluation and the quality development in higher education. (Email: drkhalidmk70@gmail. com; kalden@kku.edu)

Mr. Mohammad Ashiquee Rasool is lecturer and researcher at King Khalid University, Saudi Arabia. His interdisciplinary research involves cloud computing, education learning and assessment in higher education.(Email: ashique.rasool@gmail.com; masheq@kku.edu.sa)

Dr. Mansoor Shariff is an Assistant Professor in the department of Prosthodontics, College of Dentistry, King Khalid University, Abha. He has keen interest in the field of educational research and is the representative to the Department of dental education for his specialty. He has ongoing researches in the field of teaching and methodology evaluation.(Email: mansoor shariff@hotmail.com; msmostfa@kku.edu.sa)

Dr. Mohammad Rashid Hussain is Assistant Professor, at College Of Computer Science, King Khalid University, Abha, Saudi Arabia, and holding $\mathrm{PhD}$ degree in Information Technology. His research interest includes educational development \& review, educational data mining, cloud intelligence, mobile cloud computing and optimizations.(Email: md.rh16780@gmail.com; humohammad@kku.edu.sa).

Article submitted 2019-02-06. Resubmitted 2019-03-05. Final acceptance 2019-03-05. Final version published as submitted by the authors. 